\title{
Frequency of beryllium-specific, central memory CD4+ T cells in blood determines proliferative response
}

\author{
Andrew P. Fontenot, ${ }^{1,2}$ Brent E. Palmer, ${ }^{1}$ Andrew K. Sullivan, ${ }^{1}$ Fenneke G. Joslin, ${ }^{1}$ \\ Cara C. Wilson, ${ }^{1,2}$ Lisa A. Maier, ${ }^{1,3,4}$ Lee S. Newman,1,3,4 and Brian L. Kotzin,1,2,4
}

1Department of Medicine, '2Department of Immunology, and ${ }^{3}$ Department of Preventive Medicine and Biometrics, University of Colorado Health Sciences Center, Denver, Colorado, USA. ${ }^{4}$ Department of Medicine, National Jewish Medical and Research Center, Denver, Colorado, USA.

\begin{abstract}
Beryllium exposure can lead to the development of beryllium-specific $\mathrm{CD}^{+} \mathrm{T}$ cells and chronic beryllium disease (CBD), which is characterized by the presence of lung granulomas and a $\mathrm{CD}^{+} \mathrm{T}$ cell alveolitis. Studies have documented the presence of proliferating and cytokine-secreting $\mathrm{CD}^{+} \mathrm{T}$ cells in blood of CBD patients after beryllium stimulation. However, some patients were noted to have cytokine-secreting $\mathrm{CD}^{+} \mathrm{T}^{\mathrm{c}}$ cells in blood in the absence of beryllium-induced proliferation, and overall, the correlation between the 2 types of responses was poor. We hypothesized that the relative proportion of memory $T$ cell subsets determined antigen-specific proliferation. In most CBD patients, the majority of beryllium-specific $\mathrm{CD} 4^{+} \mathrm{T}$ cells in blood expressed an effector memory $\mathrm{T}$ cell maturation phenotype. However, the ability of blood cells to proliferate in the presence of beryllium strongly correlated with the fraction expressing a central memory $T$ cell phenotype. In addition, we found a direct correlation between the percentage of beryllium-specific $\mathrm{CD}^{+} \mathrm{T}_{\mathrm{EM}}$ cells in blood and $\mathrm{T}$ cell lymphocytosis in the lung. Together, these findings indicate that the functional capability of antigen-specific $\mathrm{CD}^{+} \mathrm{T}$ cells is determined by the relative proportion of memory $\mathrm{T}$ cell subsets, which may reflect internal organ involvement.
\end{abstract}

\section{Introduction}

With a known antigen and an accessible target organ, chronic beryllium disease (CBD) serves as an important model of an organ-specific immune-mediated disease. This disorder occurs in susceptible individuals exposed to beryllium in the workplace, and more than 1 million workers are at risk for the development of CBD (1-5). Beryllium sensitization is associated with the presence of circulating beryllium-specific $\mathrm{CD}^{+} \mathrm{T}$ cells, which proliferate in the presence of beryllium salts in culture in an MHC class II-restricted manner (6-10). The in vitro response forms the basis of the beryllium lymphocyte proliferation test (BeLPT), which is currently used to detect beryllium sensitization in the workplace (11-13). Progression from sensitization to CBD occurs at a rate of $6-8 \%$ per year (14) and is characterized by the accumulation of large numbers of berylliumspecific, Th1-type cytokine-secreting $\mathrm{CD}^{+} \mathrm{T}$ cells in the lung and granulomatous inflammation. Important differences exist between antigen-specific $\mathrm{T}$ cells that reside in the lung and those present in the circulation. For example, beryllium-specific memory $\mathrm{CD}^{+} \mathrm{T}$ cells in blood remain dependent on CD28 engagement for optimal $\mathrm{T}$ cell activation, while the memory $\mathrm{CD}^{+} \mathrm{T}$ cells present in bronchoalveolar lavage (BAL) no longer require CD28 costimulation for either proliferation or Th1-type cytokine secretion; this suggests a maturation within the memory $\mathrm{CD}^{+} \mathrm{T}$ cell population (15).

Using ELISPOT analysis, we found significant numbers of IFN- $\gamma$ secreting $\mathrm{CD}^{+} \mathrm{T}$ cells when peripheral blood cells from CBD

Nonstandard abbreviations used: BAL, bronchoalveolar lavage; BeLPT, beryllium lymphocyte proliferation test; $\mathrm{BeS}$, beryllium-sensitized; $\mathrm{BeSO}_{4}$, beryllium sulfate; $\mathrm{CBD}$, chronic beryllium disease; $\mathrm{SEB}$, staphylococcal enterotoxin $\mathrm{B} ; \mathrm{T}_{\mathrm{CM}}$, central memory $\mathrm{T}$ (cell); $\mathrm{T}_{\mathrm{EM}}$, effector memory $\mathrm{T}$ (cell).

Conflict of interest: The authors have declared that no conflict of interest exists.

Citation for this article: J. Clin. Invest. 115:2886-2893 (2005).

doi:10.1172/JCI24908. patients were stimulated with beryllium salts in culture (16). The correlation between cytokine secretion and proliferative responses was poor. Furthermore, we identified 13 subjects with berylliumspecific, IFN- $\gamma$-secreting $\mathrm{T}$ cells in blood yet no beryllium-induced lymphoproliferation. These findings suggested that low beryllium-induced proliferation with cells from some CBD patients is due to a different proliferative capacity rather than the absence of beryllium-specific $\mathrm{CD}^{+} \mathrm{T}$ cells. We hypothesized that this reduced proliferative response might parallel differences in memory $\mathrm{T}$ cell maturation. Recent studies suggest that memory $T$ cells of different maturation states possess different migratory and functional capabilities $(17,18)$. Based on the expression of the lymph node homing receptor CCR7 and the CD45RA isoform, at least 2 subsets of memory cells exist (17-21). Central memory $\mathrm{T}\left(\mathrm{T}_{\mathrm{CM}}\right)$ cells have lost the expression of CD45RA while retaining CCR7 expression. Retention of CCR7 expression renders cells capable of entering lymph nodes and recirculating between blood and lymph (22). In contrast, effector memory $\mathrm{T}\left(\mathrm{T}_{\mathrm{EM}}\right)$ cells have downregulated the expression of both CD45RA and CCR7 and migrate to and reside in target organs such as the lung. $\mathrm{T}_{\mathrm{CM}}$ cells appear capable of differentiating into $\mathrm{T}_{\mathrm{EM}}$ cells upon restimulation. Based on this paradigm, $\mathrm{T}_{\mathrm{EM}}$ and $\mathrm{T}_{\mathrm{CM}}$ cells are thought to play complementary roles when reexposed to antigen. The $\mathrm{T}_{\mathrm{EM}}$ cells provide rapid effector function within the target organ, while the $\mathrm{T}_{\mathrm{CM}}$ cells proliferate in the lymph node, generating increased numbers of effector cells $(17,18)$.

In this study, we analyzed the Th1-type cytokine profile, proliferative capacity, and maturation phenotype of beryllium-specific CD4 ${ }^{+}$ $\mathrm{T}$ cells in blood and BAL of CBD and beryllium-sensitized (BeS) subjects. No correlation between the frequencies of beryllium-specific, Th1-type cytokine-expressing $\mathrm{CD}^{+} \mathrm{T}$ cells in blood and beryllium-induced $\mathrm{T}$ cell proliferation in culture was seen. The majority of beryllium-specific $\mathrm{CD}^{+} \mathrm{T}$ cells in blood and BAL expressed a 
A
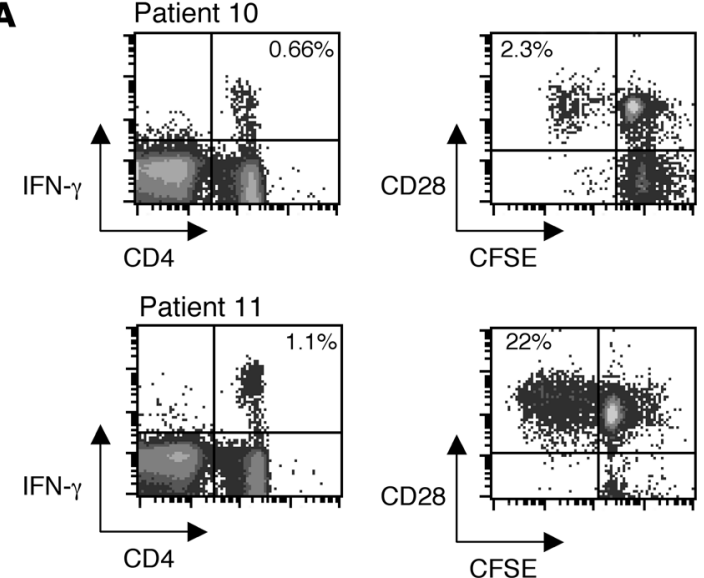

B
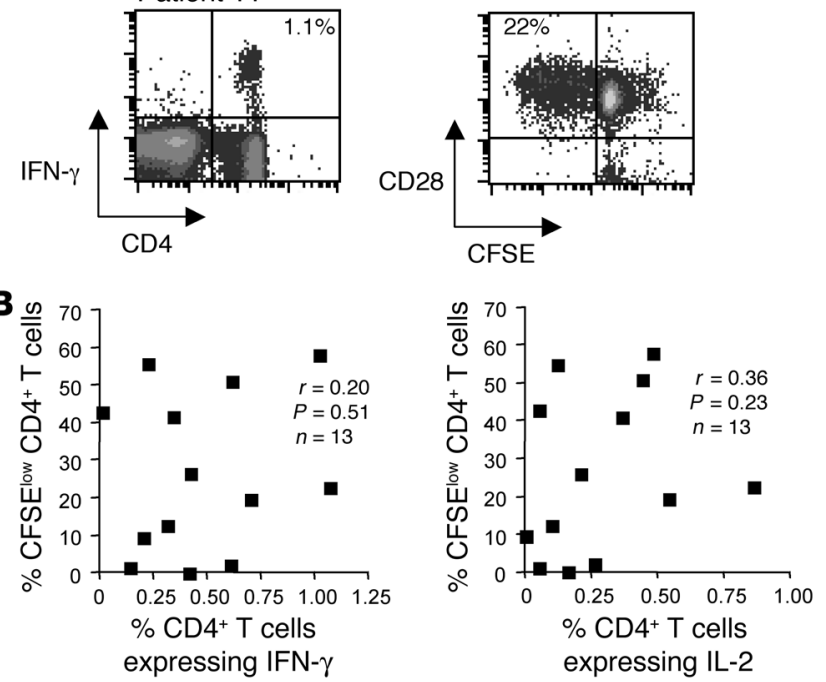

$T_{E M}$ cell phenotype, and we observed a correlation between percentage of beryllium-specific $\mathrm{T}_{\mathrm{EM}}$ cells in blood and lymphocytosis in BAL. In contrast, proliferation of blood $\mathrm{CD} 4^{+} \mathrm{T}$ cells in response to beryllium was closely tied to the proportion of antigen-specific cells expressing a $\mathrm{T}_{\mathrm{CM}}$ phenotype. These results suggest that the functional properties of the beryllium-specific $\mathrm{CD} 4^{+} \mathrm{T}$ cell in blood are determined by the relative proportion of memory $\mathrm{T}$ cell subsets, which is influenced by the degree of target organ inflammation.

\section{Results}

Lack of correlation between proliferating and cytokine-secreting responses after stimulation of blood $\mathrm{CD}^{+} \mathrm{T}$ cells with beryllium. Our previous studies have detected the presence of beryllium-specific, cytokineproducing $\mathrm{CD}^{+} \mathrm{T}$ cells in the blood of some $\mathrm{CBD}$ patients in the absence of a beryllium-induced proliferative response (16). These findings raise the possibility that patients may have different subsets of beryllium-specific memory $\mathrm{T}$ cells in blood. To further assess this possibility, fresh PBMCs from 13 CBD patients were CFSE-labeled and cultured in the presence of medium alone or $1 \times 10^{-4} \mathrm{M}$ beryllium sulfate $\left(\mathrm{BeSO}_{4}\right)$ for 7 days. At the same time point, the frequency of beryllium-specific, Th1-type cytokineexpressing $\mathrm{CD}^{+} \mathrm{T}$ cells in blood was determined. Two representative examples of patient responses are shown in Figure 1A. The frequency of beryllium-specific, IFN- $\gamma$-secreting $\mathrm{CD}^{+} \mathrm{T}$ cells in the blood of patients 10 and 11 was $0.66 \%$ and $1.1 \%$, respectively (Figure 1A). Marked differences in the ability of the beryllium-specific $\mathrm{CD}^{+} \mathrm{T}$ cells from these 2 subjects to proliferate (i.e., lose CFSE expression) after $\mathrm{BeSO}_{4}$ exposure were noted. For example, $22 \%$ of the $\mathrm{CD} 28^{+} \mathrm{CD} 4^{+} \mathrm{T}$ cells from patient 11 underwent berylliuminduced proliferation (CFSE low) after 7 days of culture compared with only $2.3 \%$ for patient 10 (Figure $1 \mathrm{~A}$ ). Nearly all proliferating $\mathrm{CD}^{+} \mathrm{T}$ cells expressed the costimulatory molecule CD28 (15).

\section{Figure 1}

Frequency of beryllium-specific CD4+ $\mathrm{T}$ cells in blood and berylliuminduced CD4+ $\mathrm{T}$ cell proliferation. (A) Representative examples of beryllium-induced intracellular IFN- $\gamma$ expression from the blood of 2 CBD patients are shown (left density plots). The number in the top right quadrant of the density plots indicates the percentage of $\mathrm{CD} 4^{+} \mathrm{T}$ cells expressing IFN- $\gamma$ after short-term exposure to $1 \times 10^{-4} \mathrm{M} \mathrm{BeSO}_{4}$. Beryllium-induced proliferation as detected by loss of CFSE labeling (right density plots) after exposure to $1 \times 10^{-4} \mathrm{M} \mathrm{BeSO}_{4}$ for 7 days in culture for the same $2 \mathrm{CBD}$ patients is shown. After gating on CD4+ T cells, loss of CFSE expression in relation to the costimulatory molecule CD28 is shown. The number in the top left quadrant of the density plots indicates the percentage of $\mathrm{CD}^{+} \mathrm{T}$ cells proliferating after 7 days of culture in the presence of $1 \times 10^{-4} \mathrm{M} \mathrm{BeSO}_{4}$. (B) Correlation of lymphoproliferation as measured by loss of CFSE expression on CD4 ${ }^{+} \mathrm{T}$ cells and berylliuminduced IFN- $\gamma$ (left) and IL-2 expression (right) is shown.

Overall, we observed no correlation between the ability of $\mathrm{CD}^{+} \mathrm{T}$ cells to proliferate (i.e., percentage CFSE-low cells) and their ability to generate IFN- $\gamma(r=0.20 ; P=0.51)$ or IL-2 $(r=0.36 ; P=0.23)$ when stimulated with $\mathrm{BeSO}_{4}$ (Figure $\left.1 \mathrm{~B}\right)$. Consistent with the lack of correlation, 3 subjects with substantial populations of berylliumresponsive, Th1-type cytokine-expressing $\mathrm{CD}^{+} \mathrm{T}$ cells in blood (ranging from $0.14 \%$ to $0.66 \%$ of total blood $\mathrm{CD}^{+} \mathrm{T}$ cells) demonstrated minimal beryllium-induced $\mathrm{T}$ cell proliferation (Figure 1B). On the other hand, 2 subjects had vigorous beryllium-induced proliferation despite low numbers of beryllium-induced, cytokinesecreting $\mathrm{CD}^{+} \mathrm{T}$ cells in blood. For example, in $1 \mathrm{CBD}$ patient, $0.2 \%$ of ex vivo $\mathrm{CD}^{+} \mathrm{T}$ cells expressed IFN- $\gamma$ after beryllium exposure, while $55 \%$ of $\mathrm{CD}^{+} \mathrm{T}$ cells from this subject exhibited beryllium-induced proliferation after 7 days of culture (Figure 1B).

Characterization of memory $\mathrm{CD} 4^{+} \mathrm{T}$ cell populations in the blood of $\mathrm{CBD}$ and BeS individuals. Surface staining of blood $\mathrm{CD} 4^{+} \mathrm{T}$ cells for CD45RA and CCR7 has identified 3 distinct $T$ cell populations: naive $\left(\mathrm{CCR} 7^{+} \mathrm{CD} 45 \mathrm{RA}^{+}\right)$, central memory $\left(\mathrm{T}_{\mathrm{CM}}\right.$; CCR7 $\left.{ }^{+} \mathrm{CD} 45 \mathrm{RA}^{-}\right)$, and effector memory ( $\mathrm{T}_{\mathrm{EM}}$; CCR7-CD45RA-) T cells. To determine whether the distribution of these memory cell subsets was altered in our study population, we examined total blood $\mathrm{CD}^{+} \mathrm{T}$ cell population in $20 \mathrm{CBD}, 9 \mathrm{BeS}$, and 9 normal control subjects for these subpopulations. In Figure 2A, a representative example of immunofluorescent staining is shown, with $49 \%$ of the CD $4^{+}$ $\mathrm{T}$ cells expressing a naive phenotype, $40 \%$ expressing a $\mathrm{T}_{\mathrm{CM}}$ phenotype, and $\mathrm{T}_{\mathrm{EM}}$ cells accounting for the remaining $11 \%$ of blood $\mathrm{CD}^{+} \mathrm{T}$ cells. Unlike CD8 ${ }^{+} \mathrm{T}$ cells, very few, if any, $\mathrm{CD}^{+} \mathrm{T}$ cells re-express CD45RA ( $<0.01 \%$ in the example shown) (17). Considerable overlap was seen among the study groups in the overall percentages of $\mathrm{CD}^{+} \mathrm{T}$ cells expressing these phenotypes (Figure 2 , B-D). Although a slightly higher median $\mathrm{T}_{\mathrm{EM}}$ percentage was measured in the CBD group (16.7\%) compared with the BeS and normal control subjects (median percentage of $10.8 \%$ and $10.5 \%$, respectively), no significant differences were noted.

Memory phenotype of beryllium-specific $C D 4^{+} T$ cells. To determine the maturation state of beryllium-specific $\mathrm{CD}^{+} \mathrm{T}$ cells, we stimulated PBMCs with $1 \times 10^{-4} \mathrm{M} \mathrm{BeSO}_{4}$ for 6 hours and analyzed IFN- $\gamma$ - and IL-2-expressing $\mathrm{CD}^{+} \mathrm{T}$ cells for surface expression of CD45RA and CCR7 (Figure 3). In order to ensure that enough gated events were observed, only subjects with at least $0.04 \%$ IFN- $\gamma$ - and IL-2-secreting beryllium-specific CD $4^{+} \mathrm{T}$ cells in blood were studied. For the CBD patient shown in Figure 3A, 1.0\% of the CD $4^{+} \mathrm{T}$ cells expressed IFN- $\gamma$ after beryllium stimulation. The majority (69\%) of these cells 

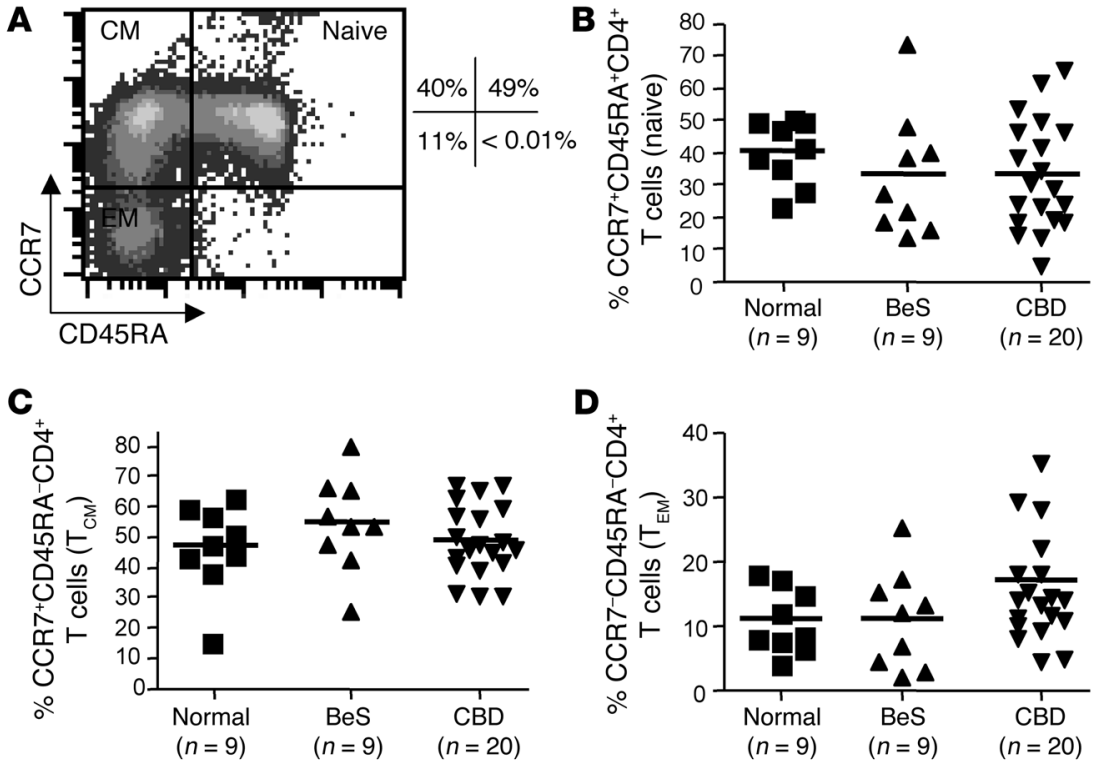

Figure 2

Expression of CCR7 and CD45RA on the total CD4+ $\mathrm{T}$ cell population. (A) Representative example of CCR7 and CD45RA expression on gated $\mathrm{CD}^{+}{ }^{+} \mathrm{CD} 4^{+} \mathrm{T}$ cells is shown. (B-D) Naive $\left(\mathrm{CCR}^{+}{ }^{+} \mathrm{CD}^{4} 5 \mathrm{RA}^{+}\right)(\mathrm{B}), \mathrm{T}_{\mathrm{CM}}\left(\mathrm{CCR} 7{ }^{+}{ }^{-} \mathrm{CD} 45 \mathrm{RA}^{-}\right)$ (C), and $\mathrm{T}_{\mathrm{EM}}\left(\mathrm{CCR} 7^{-} \mathrm{CD}^{-}\right.$R $\left.^{-} \mathrm{A}^{-}\right)$(D) phenotypes were assessed on the total $\mathrm{CD}^{+}{ }^{+} \mathrm{CD} 4^{+} \mathrm{T}$ cell population from 9 normal control subjects, $9 \mathrm{BeS}$ patients, and $20 \mathrm{CBD}$ patients. The median percentage of $C D 4+T$ cells expressing each maturation phenotype is shown as a solid line. expressed a $\mathrm{T}_{\mathrm{EM}}$ cell phenotype, compared with $31 \% \mathrm{~T}_{\mathrm{CM}}$ cells. As expected, the naive $\mathrm{CD} 4^{+} \mathrm{T}$ cell population did not include beryllium-responsive cytokine-secreting cells. Similar proportions of IFN- $\gamma$-expressing $C D 4^{+} \mathrm{T}_{\mathrm{EM}}$ and $\mathrm{T}_{\mathrm{CM}}$ cells were seen after staphylococcal enterotoxin B (SEB) stimulation (Figure 3B) as compared with beryllium stimulation. Few, if any, $\mathrm{CD}^{+} \mathrm{T}$ cells stained positively for IFN- $\gamma$ after $\mathrm{BeSO}_{4}$ stimulation, whereas $\mathrm{CD}^{+}$cells capable of IFN- $\gamma$ secretion were present in the blood of this patient and expressed IFN- $\gamma$ after SEB stimulation (data not shown).

Analysis of IL-2 secretion in the same individual showed that $0.5 \%$ of the $\mathrm{CD}^{+} \mathrm{T}$ cells expressed this cytokine following $\mathrm{BeSO}_{4}$ exposure (Figure 3C). A similar percentage of these cells expressed the $\mathrm{T}_{\mathrm{EM}}, \mathrm{T}_{\mathrm{CM}}$, and naive phenotypes compared with IFN- $\gamma^{+}$cells generated under the same conditions. However, when cells were stimulated by SEB, the majority of IL-2-expressing cells had a $T_{C M}$ phenotype (57\%), and $15 \%$ expressed a naive phenotype (Figure 3D). Thus, SEB stimulation appears to reveal IL-2-producing $\mathrm{CD} 4^{+} \mathrm{T}$ cells that are less differentiated (i.e., more $\mathrm{T}_{\mathrm{CM}}$ cells than $\mathrm{T}_{\mathrm{EM}}$ cells) compared with those secreting IFN- $\gamma$ under the same conditions, being more representative of the total $\mathrm{CD} 4^{+} \mathrm{T}$ cell population.

Figure 4 shows the maturation states of IFN- $\gamma$ - and IL-2-producing beryllium-specific $\mathrm{CD}^{+} \mathrm{T}$ cells in blood for all CBD $(n=12)$ and $\operatorname{BeS}(n=3)$ patients evaluated. Because of the low frequency of beryllium-specific cells in the blood of BeS patients, we identified only $3 \mathrm{BeS}$ individuals with sufficient numbers of

\section{Figure 3}

Maturation phenotype staining of beryllium-specific IFN- $\gamma-$ and IL-2expressing $\mathrm{CD}_{4}{ }^{+} \mathrm{T}$ cells in blood of a representative CBD subject. Intracellular expression of IFN- $\gamma$ (A, left) and IL-2 (C, left) after a 6-hour stimulation with $1 \times 10^{-4} \mathrm{M} \mathrm{BeSO}_{4}$ is shown. In addition, expression of intracellular IFN- $\gamma(\mathbf{B}$, left) and IL-2 (D, left) after SEB stimulation is shown. The percentage of CD4+ $\mathrm{T}$ cells expressing the various Th1type cytokines is shown in the upper right of each density plot. The expression of CCR7 and CD45RA in the IFN- $\gamma$-expressing (A and B, right) and IL-2-expressing ( $\mathbf{C}$ and $\mathbf{D}$, right) $\mathrm{CD} 4^{+} \mathrm{T}$ cells was then determined, and the percentage of $\mathrm{CD} 4^{+} \mathrm{T}$ cells in each quadrant of the density plots is shown. these cells to evaluate using intracellular cytokine staining. The median percentage of beryllium-specific, IFN- $\gamma$-expressing CD $4^{+}$ $T$ cells with a $T_{E M}$ phenotype (76\%, range $\left.31-96 \%\right)$ was significantly greater than the median percentage of those with either a $\mathrm{T}_{\mathrm{CM}}(24 \%$, range $3.2-69 \% ; P<0.001)$ or a naive $(0 \%$, range $0-0.7 \%$; $P<0.001)$ phenotype (Figure 4A, left). Similar findings were seen
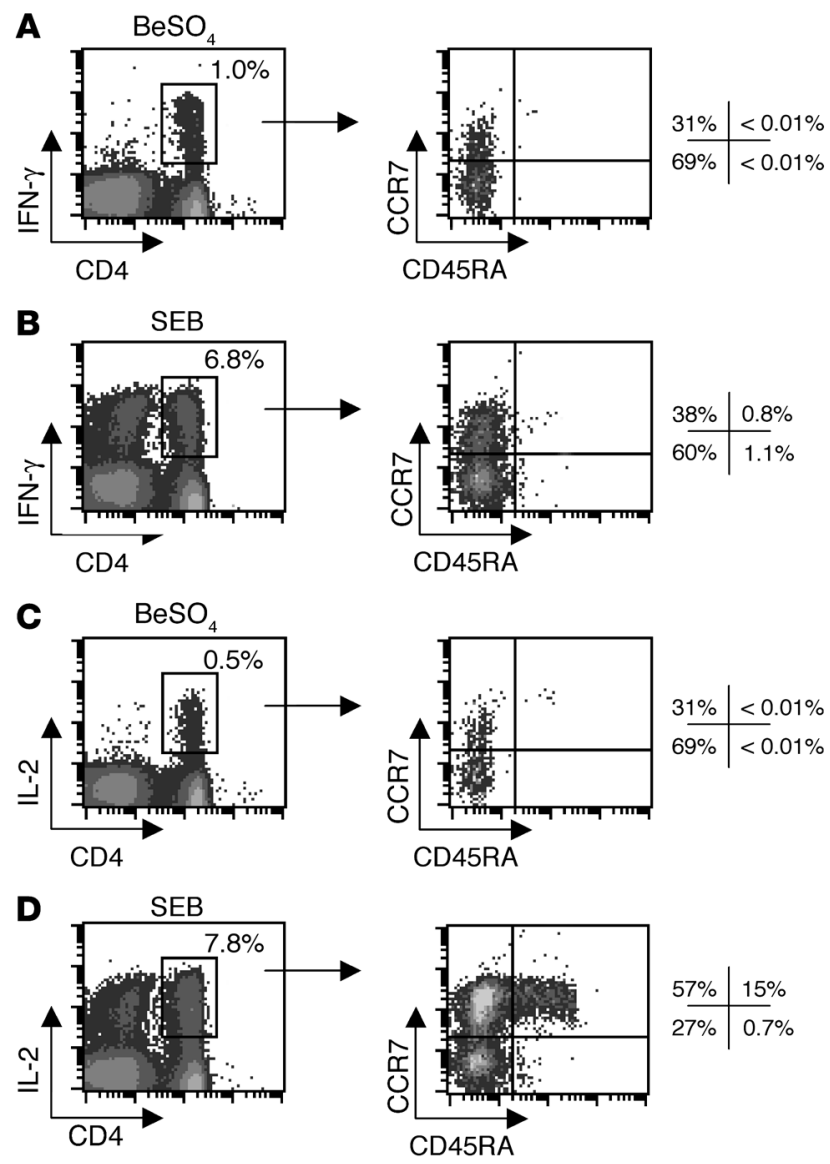
A
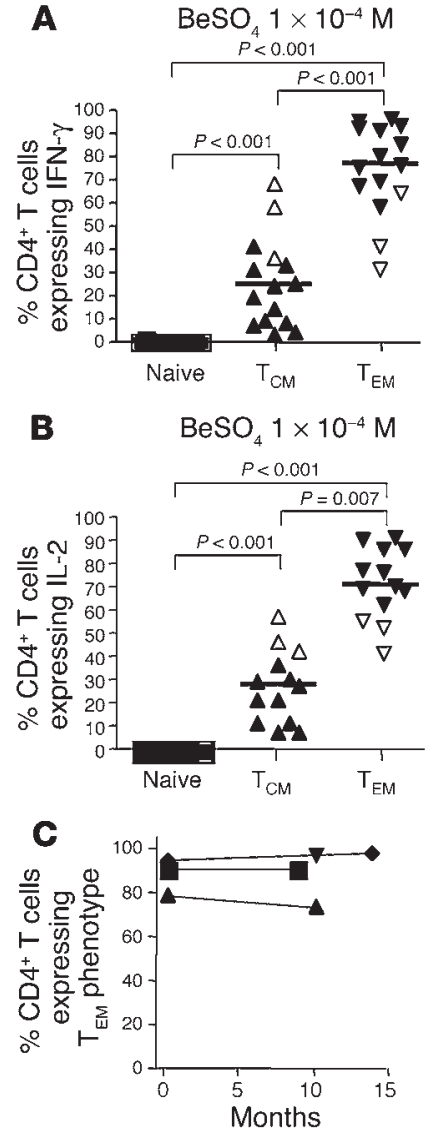

for SEB-stimulated IFN- $\gamma$-expressing $\mathrm{CD}^{+} \mathrm{T}$ cells, except that the median percentage of $\mathrm{T}_{\text {ЕM }}$ cells among SEB-stimulated cells was slightly lower than that among $\mathrm{BeSO}_{4}$-responsive cells $(57 \%$ $\mathrm{T}_{\mathrm{EM}}$ cells, range $19-80 \% ; 38 \% \mathrm{~T}_{\mathrm{CM}}$ cells, range $\left.15-79 \% ; P<0.001\right)$ (Figure $4 \mathrm{~A}$, right). We were able to identify $10 \mathrm{CBD}$ patients and 3 BeS subjects with frequencies of at least $0.04 \%$ for IL-2-secreting beryllium-specific cells. Again, the majority of these cells expressed a $\mathrm{T}_{\text {ЕM }}$ phenotype $(72 \%$, range $42-92 \%)$ with the remainder being $\mathrm{T}_{\mathrm{CM}}$ cells $(28 \%$, range $8.2-58 \% ; P<0.01)$. On the other hand, as shown in Figure 4B, the maturation profile for SEB-responsive, IL-2-expressing $\mathrm{CD} 4^{+} \mathrm{T}$ cells was markedly different, with a significantly higher median percentage of $\mathrm{T}_{\mathrm{CM}}$ cells $(64 \%$, range $43-83 \%)$ as compared with either $\mathrm{T}_{\mathrm{EM}}(24 \%$, range $10-47 \% ; P<0.001)$ or naive cells $(6.8 \%$, range $0-27 \% ; P<0.001)$. In order to determine that no change in the maturation phenotype occurred during the 6-hour stimulation, blood from 3 CBD patients was sorted into $\mathrm{T}_{\mathrm{CM}}$ and $\mathrm{T}_{\mathrm{EM}}$ subsets and stimulated with either medium alone, plate-bound anti-CD3 plus $3 \mu \mathrm{g} / \mathrm{ml}$ anti-CD28, or SEB. Despite T cell activation after short-term culture, no change in the memory cell phenotype was seen. For example, the percentage of $C D 4^{+} \mathrm{T}_{\mathrm{CM}}$ cells before and after short-term culture in the presence of SEB was $97 \% \pm 0.1 \%$ and $97 \% \pm 0.9 \%$, respectively (data not shown).

Interestingly, there appeared to be a higher proportion of beryllium-specific, IFN- $\gamma$-expressing cells with a $\mathrm{T}_{\mathrm{CM}}$ cell phenotype in the 3 BeS subjects evaluated (open symbols in Figure 4) as compared with the CBD patients (59\% versus a median of $17 \%$ in the CBD patients). A similar pattern was seen for beryllium-induced IL-2 production in the BeS subjects (47\% versus a median of $23 \%$

\section{Figure 4}

Maturation phenotype of beryllium-specific and SEB-responsive CD4+ T cells from 12 CBD patients (filled triangles) and 3 BeS subjects (open triangles). ( $\mathbf{A}$ and $\mathbf{B})$ The percentage of beryllium-specific IFN- $\gamma^{+}(\mathbf{A}$, left) and IL-2+ (B, left) $\mathrm{CD} 4+{ }^{+} \mathrm{T}$ cells displaying a particular maturation phenotype as determined by the expression of CCR7 and CD45RA is shown. In addition, the percentage of SEB-responsive IFN- $\gamma^{+}$(A, right) and $\mathrm{IL}-2^{+}$(B, right) $\mathrm{CD} 4^{+} \mathrm{T}$ cells displaying a particular maturation phenotype based on the expression of CCR7 and CD45RA is shown. The median percentage is shown as a solid line. (C) Longitudinal studies of the percentage of beryllium-specific $C D 4+T$ cells expressing a $T_{E M}$ cell phenotype over time. PBMCs were obtained from 4 CBD subjects at time intervals ranging from 7 to 14 months after the initial evaluation.

in the CBD patients). Although only $3 \mathrm{BeS}$ subjects had sufficient numbers of beryllium-specific $\mathrm{CD} 4^{+} \mathrm{T}$ cells in blood to evaluate, these findings raise the possibility that progression from sensitization to disease may be associated with a further differentiation of memory $\mathrm{T}$ cells to an effector memory phenotype.

Four CBD patients underwent repeat analysis at time intervals ranging from 7 to 14 months after the initial evaluation (Figure 4C). These subjects experienced no change in their disease status over the interval time period and possessed similar quantities of IFN- $\gamma$-expressing beryllium-specific $\mathrm{CD}^{+} \mathrm{T}$ cells at both time points (data not shown). The median percentage of beryllium-specific $\mathrm{CD} 4^{+} \mathrm{T}$ cells expressing a $\mathrm{T}_{\mathrm{EM}}$ cell phenotype was $92 \%$ (range $80-96 \%$ ) at time 0 compared with $95 \%$ (range $75-99 \% ; P=0.69$ ) at the subsequent evaluation. These findings suggest that in the presence of persistent antigen exposure, the circulating pool of $T_{E M}$ cells in beryllium disease remains stable over time.

Memory maturation phenotype determines beryllium-induced T cell proliferation in blood. To determine whether the memory cell phenotype influenced the ability of $\mathrm{CD}_{4}{ }^{+} \mathrm{T}$ cells to divide after $\mathrm{BeSO}_{4}$ exposure, PBMCs from $12 \mathrm{CBD}$ patients were stimulated with $\mathrm{BeSO}_{4}$ in culture for 7 days, and $C D 4^{+} T$ cell proliferation was assessed using the CFSE-based proliferation assay. As shown in Figure 5A (top left), $20 \%$ of the IFN- $\gamma$-expressing $\mathrm{CD}_{4}^{+} \mathrm{T}$ cells after $\mathrm{BeSO}_{4}$ exposure displayed a $\mathrm{T}_{\mathrm{CM}}$ cell phenotype. After culture of fresh PBMCs from this individual for 7 days in the presence of $1 \times 10^{-4} \mathrm{M} \mathrm{BeSO}_{4}$, $52 \%$ of $\mathrm{CD}^{+} \mathrm{T}$ cells proliferated compared with after culture with medium alone. In contrast, only $3.2 \%$ of beryllium-induced, IFN- $\gamma$ expressing $\mathrm{CD} 4^{+} \mathrm{T}$ cells from another $\mathrm{CBD}$ subject displayed a $\mathrm{T}_{\mathrm{CM}}$ cell phenotype, with the remaining $97 \%$ representing berylliumspecific effector memory $\mathrm{CD}^{+} \mathrm{T}$ cells (Figure $5 \mathrm{~A}$, bottom left). Only $2.3 \%$ of the $\mathrm{CD}^{+} \mathrm{T}$ cells from this individual proliferated in response to $\mathrm{BeSO}_{4}$ exposure. Similar findings were seen with respect to beryllium-induced IL-2 expression. Overall, in $12 \mathrm{CBD}$ subjects, an inverse correlation $(r=-0.92 ; P \leq 0.0001)$ was observed between the percentage of beryllium-stimulated proliferating cells and the percentage of beryllium-specific $\mathrm{CD} 4^{+} \mathrm{T}$ cells expressing a $\mathrm{T}_{\mathrm{EM}}$ phenotype ex vivo (Figure 5B, left). Conversely, we found a significant correlation $(r=0.93 ; P \leq 0.0001)$ between beryllium-induced $\mathrm{T}$ cell proliferation and the percentage of beryllium-specific $\mathrm{CD} 4^{+} \mathrm{T}$ cells expressing a $\mathrm{T}_{\mathrm{CM}}$ phenotype (Figure $5 \mathrm{~B}$, right).

Correlation of the memory phenotype of beryllium-specific $\mathrm{CD} 4^{+} T$ cells in blood and the degree of inflammation in the lung. Based on our previous observation that higher frequencies of beryllium-specific cells in blood were associated with the extent of alveolar inflammation as measured by both BAL wbc and lymphocyte counts (16), we correlated the percentage of beryllium-specific $\mathrm{CD}^{+} \mathrm{T}$ cells 

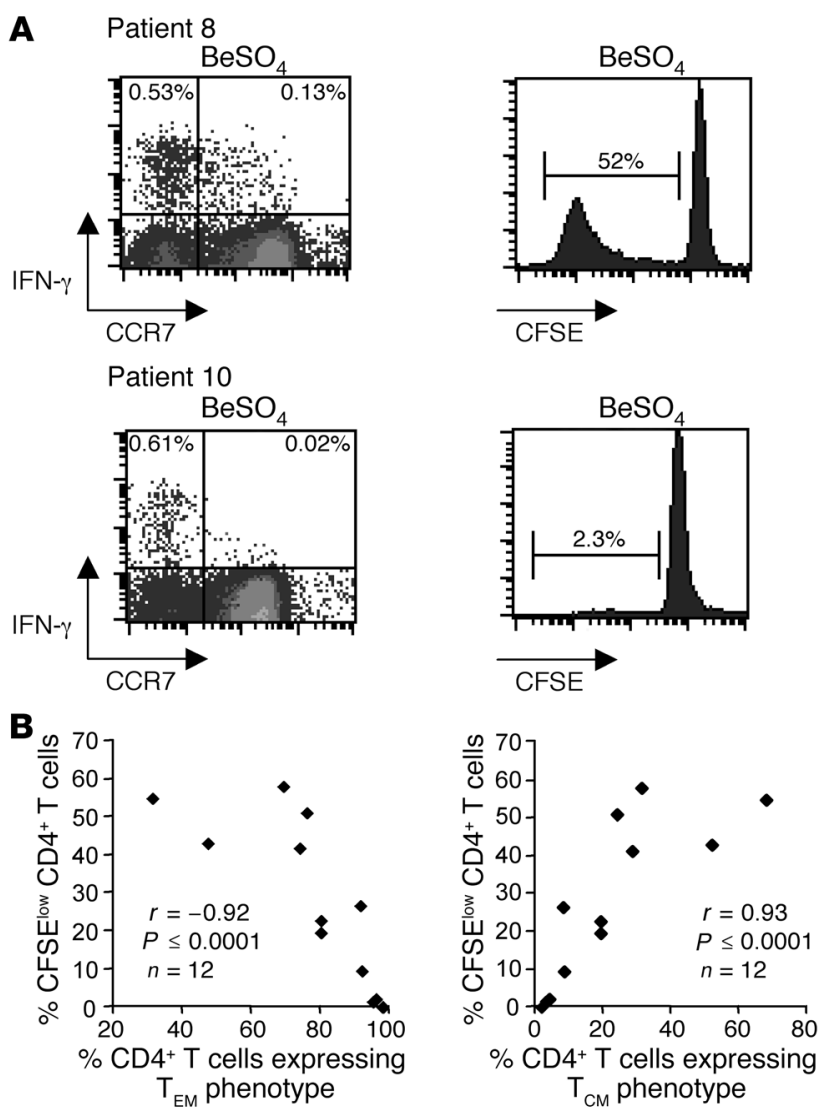

expressing a $\mathrm{T}_{\mathrm{EM}}$ phenotype in blood with these parameters of lung involvement. As shown in Figure 6, a significant positive correlation was seen for the percentage of lymphocytes in BAL $(r=0.69 ; P=0.009)$, and a trend was noted with total BAL wbc count $(r=0.49 ; P=0.09)$. Conversely, an inverse correlation was observed between the percentage of lymphocytes in BAL and the percentage of beryllium-specific $\mathrm{CD}^{+} \mathrm{T}$ cells expressing a $\mathrm{T}_{\mathrm{CM}}$ phenotype in blood $(r=-0.71 ; P=0.007)$. We did not observe a correlation between percentage of beryllium-specific CD $4^{+} \mathrm{T}$ cells expressing a $\mathrm{T}_{\mathrm{EM}}$ phenotype in blood and any pulmonary or exercise physiologic variable (data not shown). Thus, the severity of the $\mathrm{CD}^{+} \mathrm{T}$ cell-mediated inflammation in BAL is closely tied to the maturation state of circulating beryllium-specific memory $\mathrm{T}$ cells.

Comparison of the memory phenotype of beryllium-specific $\mathrm{CD}^{+} \mathrm{T}$ cells in blood and lung. Because of the inaccessibility of the target organ in most diseases, few studies have been able to compare the T cell memory phenotypes of antigen-specific cells found in blood versus the target organ. In a disease characterized by $\mathrm{CD} 4^{+} \mathrm{T}$ cell alveolitis, BAL allows the direct sampling of lung lymphocytes, with up to $25 \%$ of those $\mathrm{CD}^{+} \mathrm{T}$ cells expressing Th1-type cytokines after beryllium exposure in culture (14). Using blood and BAL from 4 of the CBD patients described above, we determined the memory phenotype of the beryllium-specific $\mathrm{CD}^{+} \mathrm{T}$ cell populations. In a representative example shown in Figure 7A, the majority of beryllium-specific, IFN- $\gamma$-expressing $\mathrm{CD}^{+} \mathrm{T}$ cells possessed a $\mathrm{T}_{\mathrm{EM}}$ cell phenotype $(97 \%$ of blood and $99 \%$ of BAL beryllium-specific CD4 $4^{+} \mathrm{T}$ cells). Overall, the percentages of beryllium-specific $\mathrm{CD} 4^{+} \mathrm{T}$ cells in blood and BAL expressing a $\mathrm{T}_{\mathrm{EM}}$ cell phenotype were similar, with a median of 94\% (range 69-96\%) in blood compared with 96\% (range 74-99\%;

\section{Figure 5}

Relationship of memory maturation phenotype of beryllium-specific CD4+ T cells and beryllium-induced T cell proliferation. (A) Representative examples of beryllium-induced IFN- $\gamma$ expression at day 0 and proliferation as measured by loss of CFSE at day 7 on gated $\mathrm{CD} 3^{+} \mathrm{CD} 4^{+}$ $T$ cells are shown for 2 CBD patients. The numbers in the top left and right quadrants of the density plots (left panel) represent the percentage of beryllium-specific CD4+ $T$ cells expressing a $\mathrm{T}_{\mathrm{EM}}\left(\mathrm{CCR} 7^{-}\right)$or $\mathrm{T}_{\mathrm{CM}}\left(\mathrm{CCR} 7^{+}\right)$cell phenotype, respectively. The percentage of $\mathrm{CD} 4^{+} \mathrm{T}$ cells losing CFSE expression after 7 days of culture in the presence of $1 \times 10^{-4} \mathrm{M} \mathrm{BeSO}_{4}$ for the respective CBD patients is shown (right panel). (B) Correlation between beryllium-induced CD4+ $\mathrm{T}$ cell proliferation and the percentage of beryllium-specific CD4+ $T$ cells expressing either a $T_{E M}$ or a $T_{C M}$ phenotype is shown.

$P=0.69)$ in BAL (Figure 7B). In addition, similar findings were seen with respect to beryllium-specific $\mathrm{CD} 4^{+} \mathrm{T}$ cells expressing a central memory phenotype in blood (median, $6.1 \%$, range $3.2-31 \%$ ) and BAL (median, $4.4 \%$, range $1.5-26 \% ; P=0.89$ ). Despite the compartmentalization of the majority of beryllium-specific $\mathrm{CD}^{+}{ }^{+} \mathrm{T}$ cells in the target organ (14), these findings suggest that beryllium-specific $\mathrm{T}_{\mathrm{EM}}$ cells are either trafficking from secondary lymphoid organs to the lung or recirculating from the lung.

\section{Discussion}

Our previous studies suggest that the frequency of berylliumspecific, cytokine-secreting $\mathrm{CD}^{+} \mathrm{T}$ cells in blood is significantly greater in CBD patients compared with individuals with beryllium sensitization (16). However, no difference in beryllium-induced $\mathrm{T}$ cell proliferation in these disease groups was seen. Furthermore, in CBD patients, the correlation between numbers of circulating beryllium-specific, cytokine-secreting $\mathrm{CD} 4^{+} \mathrm{T}$ cells and berylliumstimulated lymphoproliferation is poor. With a known antigenic stimulus and an accessible target organ, beryllium-induced disease serves as an ideal system in which to investigate the role of different human memory $\mathrm{CD}^{+} \mathrm{T}$ cell subsets in disease. Using blood and BAL from patients with beryllium sensitization and CBD, the current studies show that the majority of beryllium-specific $\mathrm{CD}^{+}$ $\mathrm{T}$ cells in blood and lung express an effector memory phenotype, irrespective of IFN- $\gamma$ or IL-2 production. Importantly, the ability of $\mathrm{CD}^{+} \mathrm{T}$ cells to proliferate after beryllium exposure in culture depends on the maturation state of the memory $T$ cell, which is significantly correlated with the severity of the $\mathrm{CD}^{+} \mathrm{T}$ cell-mediated inflammation in the lung.
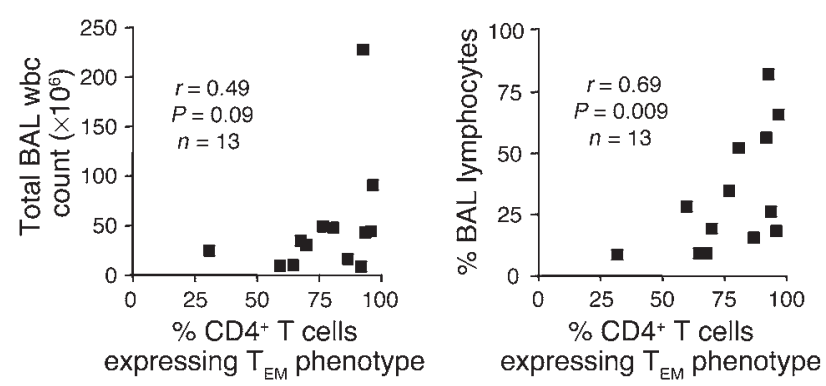

Figure 6

Correlation between the percentage of beryllium-specific CD4 ${ }^{+} T$ cells in blood expressing a $\mathrm{T}_{\mathrm{EM}}$ phenotype and total BAL wbc count or percentage of lymphocytes in BAL for $11 \mathrm{CBD}$ and 2 BeS patients. 
A

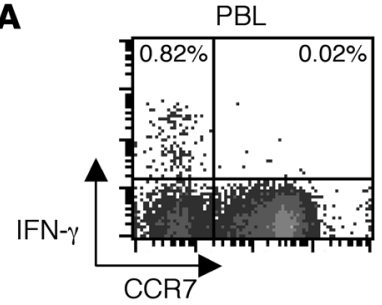

B

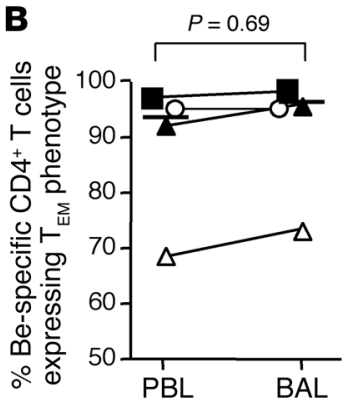

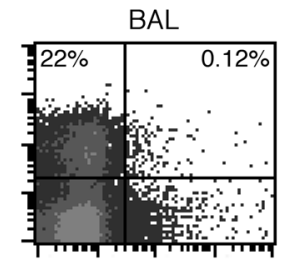

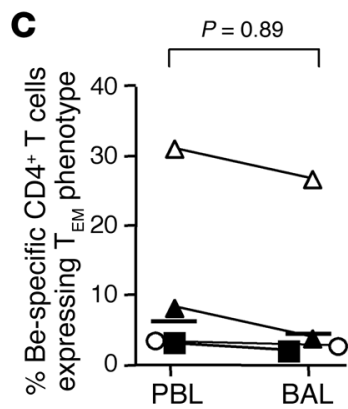

Figure 7

Beryllium-specific CD4+ ${ }^{+}$cells from blood and BAL of CBD patients express similar maturation phenotypes. (A) Beryllium-induced IFN- $\gamma$ expression on gated $\mathrm{CD} 3^{+} \mathrm{CD} 4{ }^{+} \mathrm{T}$ cells from blood and $\mathrm{BAL}$ of a representative CBD subject is shown. The numbers in the top left and right quadrants represent the percentage of beryllium-specific CD4+ $T$ cells expressing a $\mathrm{T}_{\mathrm{EM}}\left(\mathrm{CCR} 7^{-}\right)$or $\mathrm{T}_{\mathrm{CM}}\left(\mathrm{CCR} 7^{+}\right)$cell phenotype, respectively. (B and $\mathbf{C}$ ) Frequency of beryllium-specific CD4+ $\mathrm{T}$ cells expressing a $T_{E M}$ or $T_{C M}$ phenotype in blood and BAL from 4 CBD patients is shown. The median percentage of IFN- $\gamma$-secreting, beryllium-specific CD4 ${ }^{+} \mathrm{T}$ cells in blood and BAL expressing a $\mathrm{T}_{\text {EM }}$ phenotype was $94 \%$ (range 69-96\%) and 96\% (range 74-99\%), respectively. The median percentage of IFN- $\gamma$-secreting, beryllium-specific CD4+ T cells in blood and BAL expressing a $\mathrm{T}_{\mathrm{CM}}$ phenotype was $6.1 \%$ (range $3.2-31 \%$ ) and $4.4 \%$ (range $1.5-26 \%$ ), respectively. The median value is shown as a solid line.

The presence of a beryllium-specific immune response in blood is detected by the beryllium lymphocyte proliferation test (BeLPT) (11-13). This assay is used for screening and diagnosis of beryllium sensitization in the workplace and is a required component of the US Department of Energy CBD prevention program (23). However, the BeLPT is unable to distinguish between stages of beryllium-induced disease and requires that beryllium-specific cells maintain the ability to proliferate after antigen stimulation in culture. In the lung, it is clear that certain beryllium-specific CD4 ${ }^{+}$ $\mathrm{T}$ cells proliferate poorly after antigen exposure, yet maintain the ability to secrete Th1-type cytokines (9). In addition, we recently showed that ELISPOT analysis for IFN- $\gamma$ and/or IL-2 detected cytokine secretion from blood cells of $6 \mathrm{BeS}$ and $7 \mathrm{CBD}$ subjects after beryllium exposure at a time when beryllium-induced $\mathrm{T}$ cell proliferation was undetectable (16). These findings are consistent with our present observations that, despite the presence of significant quantities of beryllium-specific $\mathrm{CD}^{+} \mathrm{T}$ cells in blood, the ability of these cells to divide is closely linked to their memory $\mathrm{T}$ cell maturation state. Our findings suggest that the reduction in beryllium-induced lymphoproliferation seen in certain individuals with beryllium-induced disease is due not to the absence of circulating beryllium-specific $\mathrm{CD}^{+} \mathrm{T}$ cells but rather to a high fraction of $\mathrm{T}_{\mathrm{EM}}$ cells that are incapable of vigorous proliferation. Similar discordance between proliferation and cytokine-secreting

responses has been seen in other diseases characterized by persistent antigen exposure such as HIV (24-26).

Even in the presence of low numbers of beryllium-induced, cytokine-secreting $\mathrm{CD}^{+} \mathrm{T}$ cells in blood, an increased percentage of those cells expressing a $\mathrm{T}_{\mathrm{CM}}$ cell phenotype was associated with strong proliferation. The ability of $\mathrm{CD}^{+} \mathrm{T}_{\mathrm{CM}}$ cells to secrete IL-2 may be responsible for their enhanced proliferation, further improving their ability to mediate protective immunity. Despite the absence of a correlation between the frequency of IL-2-expressing, beryllium-specific $\mathrm{CD}^{+} \mathrm{T}$ cells in blood and lymphoproliferation $(r=0.35 ; P=0.26)$, we did observe a significant association between the frequency of beryllium-specific CD $4^{+} \mathrm{T}$ cells expressing a central memory phenotype and beryllium-induced $\mathrm{CD} 4^{+} \mathrm{T}$ cell proliferation $(r=0.92 ; P=0.0001)$. Direct proof that beryllium-specific $\mathrm{CD} 4^{+} \mathrm{T}_{\mathrm{CM}}$ cells possess a proliferative advantage over $\mathrm{T}_{\mathrm{EM}}$ cells would require separation of these cells at time 0 followed by analysis of beryllium-induced proliferation. Because of limitations on the usage of peripheral blood from CBD patients and the low frequency of beryllium-specific $\mathrm{CD}^{+} \mathrm{T}$ cells in blood, we were unable to perform these studies. However, in preliminary experiments using blood from healthy subjects stimulated with phytohemagglutinin, $\mathrm{CD}^{+} \mathrm{T}_{\mathrm{CM}}$ cells displayed greater proliferative responses compared with $\mathrm{T}_{\mathrm{EM}}$ cells (data not shown).

In the current studies of patients with beryllium-induced disease, we noted that the overall proportions of $\mathrm{CD}^{+} \mathrm{T}$ cell memory subsets were similar to those in control subjects. This is not surprising, since the circulating beryllium-specific $\mathrm{CD}^{+} \mathrm{T}$ cell population represents only a very small fraction of the total $\mathrm{CD} 4^{+} \mathrm{T}$ cell compartment $(9,16)$. When the superantigen SEB was used as a polyclonal activator, $\mathrm{CD}^{+} \mathrm{T}$ cells that secreted both IL- 2 and IFN- $\gamma$, compared with those that only made IFN- $\gamma$, were enriched in the $\mathrm{T}_{\mathrm{CM}}$ population, and even a few naive $\mathrm{CD} 4^{+}$cells were capable of secreting IL-2. However, when we focused on beryllium-specific CD4 ${ }^{+} \mathrm{T}$ cells, the $\mathrm{T}_{\mathrm{EM}}$ and $\mathrm{T}_{\mathrm{CM}}$ composition of cytokine-secreting cells was similar whether or not the cells retained the capacity to express IL-2. We found that the majority of beryllium-specific $\mathrm{CD} 4^{+}$cells that secreted both IL-2 and IFN- $\gamma$, similar to the ones that expressed IFN- $\gamma$ alone, were $T_{\mathrm{EM}}$ cells, irrespective of their location in blood or the target organ. In addition, the memory phenotype of the beryllium-specific $\mathrm{CD}^{+} \mathrm{T}$ cells in blood mirrored that expressed by the beryllium-specific cells in the target organ.

We have previously shown that 2 populations of beryllium-specific $\mathrm{CD}^{+} \mathrm{T}$ cells exist in blood and BAL of CBD patients: those cells capable of secreting both IFN- $\gamma$ and IL-2 and those only able to express IFN- $\gamma(9,16)$. Few, if any, beryllium-specific CD4 ${ }^{+}$ $\mathrm{T}$ cells secreted only IL-2. These observations are very similar to those reported in persistent viral infections such as progressive $\mathrm{HIV}$ infection in which virus-specific $\mathrm{CD} 4^{+} \mathrm{T}$ cells primarily produce IFN- $\gamma$ and little, if any, IL-2 $(24,26,27)$. However, when viral antigen burden is reduced by the administration of highly active antiretroviral therapy, a partial recovery of IL-2-producing $\mathrm{T}_{\mathrm{CM}}$ cells is seen $(24,27)$. It has also been shown in a perforin-deficient murine model of chronic lymphocytic choriomeningitis virus infection that $\mathrm{T}$ cells first lose the capacity to produce IL-2, then TNF- $\alpha$, and finally IFN- $\gamma(24,27)$. Our findings suggest that persistent antigen exposure drives the beryllium-specific $\mathrm{CD} 4^{+} \mathrm{T}$ cells toward a maturation state in which their cytokine and other functional characteristics are inconsistent with a vigorous proliferative response, particularly in those subjects with an intense $\mathrm{CD}^{+} \mathrm{T}$ cell alveolitis. One limitation of our analysis is that we were only able 
Table 1

Characteristics of BeS and CBD patients ${ }^{\mathrm{A}}$

$\begin{array}{lcc}\text { Characteristics } & \begin{array}{c}\text { BeS patients } \\ (\boldsymbol{n}=\mathbf{9})\end{array} & \begin{array}{c}\text { CBD patients } \\ (\boldsymbol{n}=\mathbf{2 3})\end{array} \\ & 57(45-77) & 63(47-75) \\ \text { Age (yr) } & 6 / 3 & 22 / 1 \\ \text { Gender (M/F) } & 9 / 0 / 0 & 20 / 0 / 3 \\ \text { Race (W/AA/H) } & 0 / 2 / 7 & 0 / 12 / 11 \\ \text { Smoking status (CS/FS/NS) } & 9.1(1.0-25) & 12.8(1.8-30) \\ \text { Beryllium exposure (yr) } & 8 / 0 / 1 & 7 / 15 / 1 \\ \begin{array}{l}\text { Industry of exposure } \\ \text { (nuclear/ceramic/other) }\end{array} & & \\ \text { Treatment } & 9 / 0 / 0 & 9 / 8 / 5 \\ \text { (none/prednisone/methotrexate) } & & \\ \text { BeLPT, stimulation index } & & \\ \quad \text { PBL } & 9.9(1.2-83) & 4.6(0.9-85) \\ \quad \text { BAL } & 3.1(1.1-6.5) & 11.2(1-262)^{B} \\ \text { BAL cells } & & \\ \quad \text { wbc count }\left(\times 10^{6}\right) & 24(13-68) & 36(10-230) \\ \quad \text { Lymphocytes }(\%) & 9.1(1.0-22) & 27(1-87)^{B} \\ \end{array}$

${ }^{A}$ Data are expressed as median (range). ${ }^{B} P<0.05$. W, white; AA, African American; H, Hispanic; CS, current smoker; FS, former smoker; NS, never smoker.

to evaluate stages of maturation in subjects with significant quantities of beryllium-specific, Th1-type cytokine-expressing $\mathrm{CD}^{+} \mathrm{T}$ cells in blood; this resulted in a decreased sample size. We have previously shown that greater frequencies of beryllium-specific cells in blood are associated with the extent of alveolar inflammation, as measured by both BAL wbc and lymphocyte counts (16). Despite this limitation, the association between memory maturation phenotype of the circulating beryllium-specific $\mathrm{CD}^{+} \mathrm{T}$ cell and $\mathrm{T}$ cell alveolitis is quite strong, which suggests that the degree of inflammation in the target organ determines the maturation state of the beryllium-specific $T$ cell. In addition, our findings suggest that the combination of the frequency of circulating beryllium-specific $\mathrm{CD}^{+} \mathrm{T}$ cells and their memory phenotype may predict the extent of alveolitis.

Fifty percent of the CBD patients enrolled in this study were receiving immunosuppressant treatment at the time of enrollment. Of the subjects with frequencies of beryllium-specific $\mathrm{CD}^{+}$ $\mathrm{T}$ cells in blood detectable by intracellular cytokine expression (see Figure 3), 5 of 13 (38\%) were receiving immunosuppressant therapy. Our previous studies investigating the TCR repertoire of $\mathrm{CD}^{+}$ $\mathrm{T}$ cells in BAL showed persistence of clonal expansions despite the initiation of corticosteroids (6). In addition, no significant difference in the frequency of beryllium-specific $\mathrm{T}$ cells in blood was seen between treated and untreated CBD subjects (16). In the present study, a significantly increased number of lymphocytes in the BAL was seen in the treated versus the untreated subjects (data not shown). This almost certainly reflects the fact that the severity of pulmonary involvement (and the need for treatment) parallels the severity of the $\mathrm{CD}^{+} \mathrm{T}$ cell-mediated inflammation. There was no evidence that treatment status affected the parameters being measured (e.g., memory T cell maturation state) in the current study.

Of all the subjects evaluated, the $3 \mathrm{BeS}$ patients studied had the highest frequency of beryllium-specific, IL-2-expressing $\mathrm{CD} 4^{+} \mathrm{T}_{\mathrm{CM}}$ cells. These subjects also had the lowest BAL absolute lymphocyte counts. Only 1 of these subjects had a positive beryllium-induced proliferative response from BAL cells, and none had granuloma- tous inflammation in the lung. Interestingly, there was an association between the extent of lung inflammation as measured by the percentage of lymphocytes in the BAL and the percentage of beryllium-specific $\mathrm{CD}^{+} \mathrm{T}$ cells expressing a $\mathrm{T}_{\mathrm{EM}}$ phenotype in blood. Taken together, our findings support the hypothesis that disease progression and potentially disease severity may be associated with a further differentiation of memory $\mathrm{T}$ cells from a proliferationcompetent beryllium-specific CD $4^{+} \mathrm{T}_{\mathrm{CM}}$ cell to an IFN- $\gamma$-expressing, poorly proliferating $\mathrm{T}_{\mathrm{EM}}$ cell. In the presence of continuous antigenic exposure, the redevelopment of a predominantly IL-2-expressing $\mathrm{T}_{\mathrm{CM}}$ population is thus prevented. In conclusion, these findings help explain some of the variability that has been observed with the BeLPT and extend our current understanding of beryllium-induced disease and persistent antigen exposure.

\section{Methods}

Study population. Twenty-three patients with a diagnosis of CBD and $9 \mathrm{BeS}$ patients were enrolled in this study. Nine healthy non-beryllium-exposed control subjects were also enrolled. The diagnosis of CBD was established using previously defined criteria, including a history of beryllium exposure, the presence of granulomatous inflammation on lung biopsy, and a positive proliferative response of blood and/or BAL T cells to $\mathrm{BeSO}_{4}$ in vitro $(28,29)$. The diagnosis of beryllium sensitization was established based on a history of beryllium exposure, positive proliferative response of PBMCs to $\mathrm{BeSO}_{4}$ in vitro, and the absence of granulomatous inflammation or other abnormalities on lung biopsy $(30,31)$. Active smokers were excluded from enrollment. Informed consent was obtained from each patient and control subject, and the protocol was approved by the Human Subject Institutional Review Boards at the University of Colorado Health Sciences Center and National Jewish Medical and Research Center.

The demographics of the BeS and CBD patients are shown in Table 1. No difference was seen in the age of the BeS and CBD patients enrolled in this study. The majority of both subject groups were male. No difference in the estimated duration of beryllium exposure was observed in BeS and CBD subjects. Eight CBD patients were treated with oral glucocorticoids, and 5 received oral methotrexate. No difference in beryllium-induced proliferation of blood cells was seen between BeS and CBD patients. In contrast, a significant increase in the proliferation of BAL cells from CBD patients compared with BeS subjects in response to beryllium was seen (median, 11.2, range 1.0-262, versus median, 3.1, range 1.1-6.5; $P=0.02$ ). At the time of this study, BAL cells from 3 of the BeS subjects proliferated in the presence of beryllium. All clinical BeLPTs were performed in the Clinical Immunology Laboratory at National Jewish Medical and Research Center as previously described (16). CBD subjects had a statistically significant increase in the percentage of BAL lymphocytes (median, 27 , range $1-87$, versus median, 9.1 , range $1.0-22 ; P<0.005$ ) compared with BeS patients.

Preparation of peripheral blood cells and beryllium-induced $C D 4^{+} T$ cell proliferation. PBMCs were isolated from heparinized blood by Ficoll-Hypaque density gradient separation, and BAL was performed as previously described $(6,7)$. Proliferation assays were performed using fresh PBMCs $\left(10 \times 10^{6}\right.$ cells per well) labeled with $1.5 \mu \mathrm{M}$ CFSE (Invitrogen Corp.) for 20 minutes at $37^{\circ} \mathrm{C}$ and washed twice with PBS (27). The CFSE-labeled cells were cultured at $37^{\circ} \mathrm{C}$ for 7 days in a humidified $5 \% \mathrm{CO}_{2}$ atmosphere in 12-well flat-bottom microtiter plates in complete culture media containing RPMI 1640 supplemented with 10\% heat-inactivated human serum (Gemini Bio-Products), $20 \mathrm{mM}$ HEPES, $1 \mathrm{mM}$ sodium pyruvate, $100 \mathrm{U} / \mathrm{ml}$ penicillin, $100 \mu \mathrm{g} / \mathrm{ml}$ streptomycin, and $2 \mathrm{mM} \mathrm{L}$-glutamine (all from Invitrogen Corp.) with 1 of the following stimulants added: medium alone, $2.5 \mu \mathrm{g} / \mathrm{ml}$ phytohemagglutinin (Sigma-Aldrich), or $1 \times 10^{-4} \mathrm{M}$ 
$\mathrm{BeSO}_{4}$ (Brush Wellman). Cells were stained with mAbs directed against CD3 and CD4 (all from BD Biosciences - Pharmingen). The lymphocyte population was identified using forward and $90^{\circ}$ light scatter patterns, and fluorescence intensity was analyzed using a FACSCalibur cytometer (BD) as previously described $(9,15)$.

Immunofluorescence staining and analysis for intracellular cytokine expression. Since ex vivo intracellular cytokine staining assays are only able to detect circulating antigen-specific cells present at frequencies greater than approximately 1 in 2,500 cells, only subjects with at least $0.04 \%$ IFN- $\gamma$ - and IL-2-secreting beryllium-specific CD4 ${ }^{+} \mathrm{T}$ cells in blood were studied. For cytokine expression, PBMCs $\left(2 \times 10^{6}\right.$ cells $)$ and BAL cells $\left(5 \times 10^{5}\right.$ cells $)$ were placed in polypropylene tubes $(12 \times 75 \mathrm{~mm}$; Fisher Scientific) containing $1 \mathrm{ml}$ of complete culture media and $3 \mu \mathrm{g} / \mathrm{ml}$ anti-CD28 and antiCD49d (BD Biosciences - Pharmingen) with 1 of the following added: medium alone, $10 \mathrm{ng} / \mathrm{ml} \mathrm{SEB}$, or $1 \times 10^{-4} \mathrm{M} \mathrm{BeSO}_{4}$. Cells were incubated for a total of 6 hours at $37^{\circ} \mathrm{C}$ in a humidified $5 \% \mathrm{CO}_{2}$ atmosphere with $10 \mu \mathrm{g} / \mathrm{ml}$ brefeldin A added after the first hour of stimulation, as previously described $(9,15)$. After stimulation, cells were washed and stained with mAbs directed against CD4, CD45RA, and CCR7 (all from BD Biosciences - Pharmingen) as previously described $(9,15)$. Cells were washed with PBS containing $1 \%$ BSA and placed in fixation medium (CALTAG Laboratories) for 15 minutes at room temperature. After washing with PBS containing $1 \%$ BSA, cells were added to permeabilization medium (CALTAG Laboratories), and stained with mAbs directed against IFN- $\gamma$ and/or IL-2 (both from CALTAG Laboratories) for 30 minutes at $4{ }^{\circ} \mathrm{C}$. Fluorescence intensity was analyzed as described above.

Statistical analysis. ANOVA analysis was used to determine whether there was a global difference between groups. After the data were checked for overall group differences, individual contrasts were calculated to compare group means of interest. A Spearman correlation was performed to analyze the associations among beryllium-induced $\mathrm{T}$ cell proliferation, frequency of Th1-type cytokine-producing cells, and percentage of cells expressing each maturation phenotype. A $P$ value of less than 0.05 was considered statistically significant.

\section{Acknowledgments}

This work was supported by NIH grants HL62410, ES06358, and ES011810, and by the General Clinical Research Center (M01-RR0051) of Research Resources at the NIH.

Received for publication March 1, 2005, and accepted in revised form July 1, 2005.

Address correspondence to: Andrew P. Fontenot, Division of Clinical Immunology (B164), University of Colorado Health Sciences Center, 4200 East Ninth Avenue, Denver, Colorado 80262, USA. Phone: (303) 315-7601; Fax: (303) 315-7642; E-mail: andrew.fontenot@uchsc.edu.
1. Fontenot, A.P., Newman, L.S., and Kotzin, B.L. 2001. Chronic beryllium disease: $\mathrm{T}$ cell recognition of a metal presented by HLA-DP. Clin. Immunol. 100:4-14.

2. Fontenot, A.P., and Kotzin, B.L. 2003. Chronic beryllium disease: immune-mediated destruction with implications for organ-specific autoimmunity [review]. Tissue Antigens. 62:449-458.

3. Newman, L.S., and Maier, L.A. 2003. Beryllium disease. In Interstitial lung disease. 4th edition. M.I. Schwarz and T.E. King Jr., editors. B.C. Decker Inc. Hamilton, Ontario, Canada. 435-451.

4. Newman, L.S., Lloyd, J., and Daniloff, E. 1996. The natural history of beryllium sensitization and chronic beryllium disease. Environ. Health Perspect. 104(Suppl. 5):937S-943S.

5. Infante, P.F., and Newman, L.S. 2004. Beryllium exposure and chronic beryllium disease. Lancet. 363:415-416

6. Fontenot, A.P., Kotzin, B.L., Comment, C., and Newman, L.S. 1998. Expansions of T-cell subsets expressing particular $\mathrm{T}$ cell receptor variable regions in chronic beryllium disease. Am. J. Respir. Cell Mol. Biol. 18:581-589.

7. Fontenot, A.P., Falta, M.T., Freed, B.M., Newman, L.S., and Kotzin, B.L. 1999. Identification of pathogenic $T$ cells in patients with beryllium-induced lung disease. J. Immunol. 163:1019-1026.

8. Fontenot, A.P., Torres, M., Marshall, W.H., Newman, L.S., and Kotzin, B.L. 2000. Beryllium presentation to $\mathrm{CD}^{+} \mathrm{T}$ cells underlies disease susceptibility HLA-DP alleles in chronic beryllium disease. Proc. Natl. Acad. Sci. U. S. A. 97:12717-12722.

9. Fontenot, A.P., Canavera, S.J., Gharavi, L., Newman, L.S., and Kotzin, B.L. 2002. Target organ localization of memory CD4 ${ }^{+} \mathrm{T}$ cells in patients with chronic beryllium disease. J. Clin. Invest. 110:1473-1482. doi:10.1172/JCI200215846.

10. Lombardi, G., et al. 2001. HLA-DP allele-specific T cell responses to beryllium account for DP-associated susceptibility to chronic beryllium disease. J. Immunol. 166:3549-3555.
11. Maier, L.A. 2001. Beryllium health effects in the era of the beryllium lymphocyte proliferation test. Appl. Occup. Environ. Hyg. 16:514-520.

12. Frome, E.L., Newman, L.S., Cragle, D.L., Colyer, S.P., and Wambach, P.F. 2003. Identification of an abnormal beryllium lymphocyte proliferation test. Toxicology. 183:39-56.

13. Stange, A.W., Furman, F.J., and Hilmas, D.E. 2004 The beryllium lymphocyte proliferation test: relevant issues in beryllium health surveillance. Am. J. Ind. Med. 46:453-462.

14. Newman, L.S., Mroz, M.M., Balkissoon, R., and Maier, L.A. 2004. Beryllium sensitization progresses to chronic beryllium disease: a longitudinal study of disease risk. Am. J. Respir. Crit. Care Med. 171:54-60.

15. Fontenot, A.P., et al. 2003. CD28 costimulation independence of target organ versus circulating memory antigen-specific CD $4^{+} \mathrm{T}$ cells. J. Clin. Invest. 112:776-784. doi:10.1172/JCI200318317.

16. Pott, G.B., et al. 2005. The frequency of berylliumspecific, Th1-type cytokine-expressing $\mathrm{CD} 4^{+} \mathrm{T}$ cells in patients with beryllium-induced disease. J. Allergy Clin. Immunol. 115:1036-1042.

17. Sallusto, F., Lenig, D., Forster, R., Lipp, M., and Lanzavecchia, A. 1999. Two subsets of memory T lymphocytes with distinct homing potentials and effector functions. Nature. 401:708-712.

18. Sallusto, F., and Lanzavecchia, A. 2001. Exploring pathways for memory $\mathrm{T}$ cell generation. J. Clin. Invest. 108:805-806. doi:10.1172/JCI200114005.

19. Lanzavecchia, A., and Sallusto, F. 2000. Dynamics of $\mathrm{T}$ lymphocyte responses: intermediates, effectors, and memory cells [review]. Science. 290:92-97.

20. Geginat, J., Sallusto, F., and Lanzavechia, A. 2001. Cytokine-driven proliferation and differentiation of human naive, central memory, and effector memory CD4+ T cells. J. Exp. Med. 194:1711-1719.

21. Seder, R.A., and Ahmed, R. 2003. Similarities and differences in CD4+ and CD8+ effector and memory T cell generation. Nat. Immunol. 4:835-842.

22. Macallan, D.C., et al. 2004. Rapid turnover of effector-memory CD4+ T cells in healthy humans.
J. Exp. Med. 200:255-260.

23. [No authors listed]. 1999. Chronic beryllium disease prevention program. Office of Environment, Safety and Health, Department of Energy. Final rule. Fed. Regist. 64:68854-68914.

24. Palmer, B.E., Boritz, E., and Wilson, C.C. 2004. Effects of sustained HIV-1 plasma viremia on HIV-1 gag-specific CD4+ T cell maturation and function. J. Immunol. 172:3337-3347.

25. Palmer, B.E., Boritz, E., Blyveis, N., and Wilson, C.C. 2002. Discordance between frequency of human immunodeficiency virus type 1 (HIV-1)specific gamma interferon-producing CD $4+\mathrm{T}$ cells and HIV-1-specific lymphoproliferation in HIV-1infected subjects with active viral replication. J. Virol. 76:5925-5936.

26. Younes, S.A., et al. 2003. HIV-1 viremia prevents the establishment of interleukin 2-producing HIV-specific memory CD4+ T cells endowed with proliferative capacity. J. Exp. Med. 198:1909-1922.

27. Harari, A., Petitpierre, S., Vallelian, F., and Pantaleo, G. 2004. Skewed representation of functionally distinct populations of virus-specific CD4 T cells in HIV-1-infected subjects with progressive disease: changes after antiretroviral therapy. Blood. 103:966-972.

28. Newman, L.S., Kreiss, K., King, T.E., Jr., Seay, S., and Campbell, P.A. 1989. Pathologic and immunologic alterations in early stages of beryllium disease: reexamination of disease definition and natural history. Am. Rev. Respir. Dis. 139:1479-1486.

29. Rossman, M.D., et al. 1988. Proliferative response of bronchoalveolar lymphocytes to beryllium. Ann. Intern. Med. 108:687-693.

30. Newman, L.S. 1996. Significance of the blood beryllium lymphocyte proliferation test. Environ. Health Perspect. 104(Suppl. 5):S953-S956.

31. Mroz, M.M., Kreiss, K., Lezotte, D.C., Campbell, P.A., and Newman, L.S. 1991. Reexamination of the blood lymphocyte transformation test in the diagnosis of chronic beryllium disease. J. Allergy Clin. Immunol. 88:54-60. 